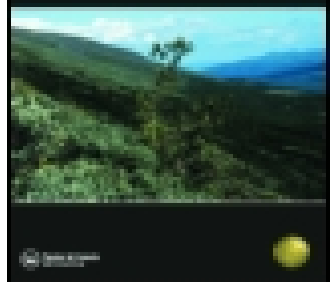

ISSN: 0374-6607 (Print) (Online) Journal homepage: http://www.tandfonline.com/loi/tped18

\title{
On Tillering
}

\section{A. Stephen Wilson Esq.}

To cite this article: A. Stephen Wilson Esq. (1883) On Tillering , Transactions of the Botanical Society of Edinburgh, 14:1-4, 350-351, DOI: 10.1080/03746608309468420

To link to this article: http://dx.doi.org/10.1080/03746608309468420

册 Published online: 01 Dec 2010.

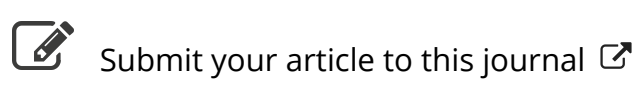

LII Article views: 4

Q View related articles ¿ 
On Tillering. By A. Stepeen Wrison, Esq., North Kinmundy, Aberdeenshire. (Photographs Exhibited).

(Read 9th February 1882.)

By the word "tillering," as applied to a cereal grass, is meant the producing of more stalks than one from a single seed. The plumule of the embryo grows into the first or primary stalk, and all the secondary stalks arise either directly from the primary stalk or from secondary stalks thus directly produced. All the secondary stalks are buds growing out of stalks, and not out of roots. Indeed, it cannot be properly said that the primary stalk itself grows from the roots; this stalk and the roots grow simultaneously, and have a biological interdependence, but the roots no more produce the stalk than a man's legs produce his head.

All the tillers or secondary stalks are thus of the nature of branches, the buds or beginnings of which arise from the two or three lowermost nodes of the primary or secondaries. No such buds are thrown out upon the internodes. The secondary stalks or tillers, which are really branches, throw out roots from their bases and lower nodes, but no stalk whatever arises directly from any root. In some plants a stalk may arise directly from a root, or a root may arise directly from a stalk, but in the grasses no stalk ever arises from off a root.

But this note is not intended to be an exposition of the principle of tillering, but merely an introduction to the photographs now exhibited of barley and oat plants.

These plants were grown in the garden at North Kinmundy, along with some others not quite so prolific, in order to test the limits of tillering. Previous experiments had shown that the main conditions necessary to ensure tillering is shallow planting. When a seed is put down 2 or 3 inches, the plumule is drawn out and exhausted before reaching the surface where the tillering arises. When a seed is merely covered with earth it goes into tillering at once. The first set of seeds were torn up by the sparrows, so that a part of the tillering season was lost. The second set were protected until safe. The best 
barley plant produced about 140 stalks, 130 of which showed the ear out of the sheath. The second had 121 ears; others had fewer, diminishing down to about fifty. The oat plant submitted stood through the winter, and produced about 10,000 returns.

Now, as the tillering process in the barleys was going on during the whole season, some of the ears were not ripe when the plants had to be pulled. But, notwithstanding this, there can be no doubt that, in order to reap the full advantage of seed corn, it should be sown or deposited as near the surface as possible. This would be true of autumn sowing as well as spring sowing, were the former not affected by frost; but a severe winter renders deeper seeding advisable for other reasons than those directly connected with the development of the seed.

\section{On Fixing Blowing Sands by means of Planted Grasses. By James Coutts Crawford, F.G.S.}

(Read 13th April 1882.)

"They manage these things better in France." If a thorough plan for fixing sands is required, we must probably go to France for an example. There large areas in the Landes and elsewhere have been reclaimed by the thorough process of enclosing the sand with brushwood, in squares of thirty yards (I think) each way, and planting the spaces thickly with Pinus maritima. Thus an article of some value is raised, the timber of these pines being sawn up for the manufacture of wine cases, and the resin which the trees yield used for covering the corks of the wine bottles.

This mode of reclaiming sandy tracts, however, must necessarily be very expensive, involving a great deal of labour; and where the climate is severe, and the locality exposed to strong winds, as in many parts of Great Britain, might probably not be successful; and it may not be amiss that I should describe certain successful operations undertaken by me in New Zealand, by which I succeeded in fixing several hundred acres of sand situated in a very unfavourable position for the purpose.

I will state what was done:-About the year $1859 \mathrm{I}$ imported $£ 5$ worth of seed of Ammophila arundinacea, 